\title{
REVIEW
}

\section{Bivalve filter feeding revisited}

\author{
C. Barker Jørgensen \\ Zoophysiological Laboratory, August Krogh Institute, Universitetsparken 13, DK-2100 Copenhagen Ø, Denmark
}

\begin{abstract}
Recent developments concerning the nature of bivalve filter feeding are reviewed and interpretations of data are examined. No convincing evidence was found for: (1) a function of mucus in the normal feeding mechanism; (2) sorting of suspended particles according to food value; (3) low rates of water processing in nature; (4) physiological control of water pumping and filtration efficiency according to nutritional needs. Recent findings are consistent with the view that the capacity for water processing is evolutionarily adapted to the concentrations of suspended food, primarily phytoplankton, that prevail in the biotope during the productive seasons of the year. 'Scope for growth', computed from measurements of the energy balance parameters, is extensively used to assess effects of environmental factors, including pollutants, on the physiology and energetıcs, particularly of mussels. Estimates tend, however, to underrate the values they are believed to reflect due to neglect of negative effects of the experimental conditions on the filter-pump. Possible effects of the experimental conditions on filtration rates should therefore be established before a calculated 'scope for growth' can be extrapolated to the habitat which the experiment simulates.
\end{abstract}

KEY WORDS: Particle capture - Role of mucus Partıcle sorting - Rates of water processing - Physiological control . 'Scope for growth'

\section{INTRODUCTION}

In a critical review of the literature on bivalve filter feeding (Jorgensen 1990), I concluded (1) that retained particulate matter that served as food normally is carried in suspension in surface currents on the gills to the mouth and down the oesophagus. Higher concentrations of suspended particles in the ambient water elicit secretion of mucus. Particles that become entangled in mucus are transferred along rejection tracts to the mouth palps, converted into pseudofaeces and ejected. (2) When mucus is produced, the chance of particles being caught, and thus ejected as pseudofaeces, depends upon size, shape and other physical characteristics of the particles, and not quality, i.e. food value. (3) Water pumping and filtration efficiency are basically autonomous processes, reflecting physical properties of the filter-pump, and they are not subject to physiological regulation at the organismic level, e.g. according to nutritional needs. Feeding in filter-feeding bivalves is thus an automatized process, retention of particulate matter being determined by the capacity of the pump and concentration of food in the ambient water. (4) The basic behavioural repertoire of filterfeeding bivalves spans from closed to fully open valves accompanied by extended mantle edges and siphon(s). The behaviour reflects the environmental conditions. Under optimal conditions the filter-pump processes the ambient water at its full capacity. Suboptimal environmental conditions, including very low or high concentrations of suspended particles, particularly phytoplankton, lack of oxygen and foul water, cause reduction of the valve gape and retraction of mantle edges and siphons, correlated with reduced water pumping. (5) The capacity for water processing is evolutionarily adapted to the concentrations of suspended food, primarily phytoplankton, that prevail in the biotope during the productive seasons of the year. During such periods the capacity for water processing enables the bivalve to more or less fully exploit its potential for growth, reproduction and/or deposition of glycogen, that is, the production potential. 
This view of the nature of bivalve filter feeding is contrary to widely held beliefs according to which mucus plays a role in normal feeding, sorting of particles is according to food value and filtration rates are controlled according to nutritional needs. The assumption that bivalve filter feeding is physiologically regulated still prevails in the literature (e.g. Hawkins \& Bayne 1992, Stenton-Dozey \& Brown 1992, Willows 1992, Bayne et al. 1993, Navarro \& Iglesias 1993, Wildish \& Saulnier 1993, MacDonald \& Ward 1994, Navarro et al. 1994, Kreeger et al. 1995, Prins et al. 1995). Recent developments in the field have therefore been reviewed and interpretations of data examined.

\section{MECHANISM OF PARTICLE RETENTION}

Particle retention in suspension-feeding bivalves implies transfer of particles from the current entering the interfilamentary spaces to the current along the frontal surface of the filaments. In bivalves with well developed latero-frontal cirri, these have traditionally been ascribed the function of straining the particles from the through-current and passing them on to the frontal ciliary tract. The function as filters was supported by Dral's (1967) observations of the pattern of beating of the cirri through the translucent valves of small undisturbed Mytilus edulis, and it seemed finally established when scanning electron microscopy showed the strikingly filter-like structure of the individual cirrus (Moore 1971, Owen 1974). Particle capture by mechanical filtration is, however, incompatible with other observations, such as disagreement between dimensions of the filters and efficiency of particle retention (Møhlenberg \& Riisgård 1978), high frictional resistance of the filters to water flow (Jørgensen 1981a), and insignificant contribution of the cirral resistance to system characteristics (Jørgensen et al. 1988). It was therefore suggested that the mechanism of particle retention was basically of fluid mechanical nature (Jørgensen 1981d, 1990)

Recent video recordings of particle trajectories near preparations of gill filaments of the mussel Mytilus edulis have further elucidated the nature of particle capture, particularly the role played by the laterofrontal. curri (Nielsen et al. 1993, Riısgård et al, 1996). In serotonin-stimulated preparations of filaments with normally beating cilia, particles in the through-current could be observed to be stopped at the level of the latero-frontal cirri and to be transferred to the frontal. current by the active beat of a cirrus. The capture mechanism was further analysed by estimates of the relative importance of the flow paths through and around the cirral filters, based on calculated frictional pressure drops across the filter. It was indicated that during normal ciliary activity the through-current driven by the lateral cilia mainly passed around the latero-frontal cirri in an oscillating unsteady 3-dimensional pattern, with little flow leaking through the filter-like net of branching cilia of the cirri.

This flow pattern is consistent with the efficiency with which particles of decreasing size are retained by the gills. Although the distance between the branching cilia of a cirrus is about $1 \mu \mathrm{m}$, only particles above about $4 \mu \mathrm{m}$ are completely retained (Møhlenberg \& Riisgârd 1978). It is thus suggested that there may never be an open flow path wider than about $4 \mu \mathrm{m}$ and that smaller particles may escape capture with increasing probability the smaller the particles.

Notably, particle capture in the bivalve gill is a process governed by low-Reynolds-number fluid mechanics where it is not crucial whether a particle is transferred with the fluid being moved by the laterofrontal cirri or in fact comes into contact with the cirri, because inertia effects and slip velocity between particle and fluid are negligible. This means that the capture of a neutrally buoyant moving particle entails moving water that surrounds the particle (Riisgård et al. 1996)

\section{ROLE OF MUCUS}

In a series of papers, Beninger, Ward and their coworkers have dealt with the role of mucus in feeding in suspension-feeding bivalves. Early microanatomical and histological studies of the pallial organs in the scallop Placopecten magellanicus disclosed an abundance of mucocytes on gill filaments, labial palps and lips which suggested a role in ingestion of food particles (Beninger et al. 1988, 1990a, b). Moreover, a histological examination of the buccal and oesophageal regions of $P$. magellanicus and 4 other suspension-feeding bivalves showed the presence of mucus and mucusparticle masses in the peribuccal and buccal regions and in the oesophagus, even in non-fed animals. Thus, abundant mucus was observed in the oesophagus of specimens of $P$. magellanicus which had heen held without feeding for over 2 mo, and the oesophagus of dry-stored oysters Crassostrea virginica contained significant amounts of mucus. It therefore seemed that a considerable basal amount of mucus is continuously produced and ingested, regardless of particle concentration in the external medium (Beninger et al. 1991).

Subsequent video-endoscopic studies further corroborated the role of mucus in suspension-feeding bivalves (Ward et al. 1991, 1993, 1994, Beninger et al. $1992,1993)$. The observations confirmed that on the plicate gills of scallops and oysters, suspended particles in the through-current are mainly directed toward 
the plical troughs and trapped in the ciliary currents over the principal filaments, consistent with capture and post-capture handling of suspended particles by means of fluid mechanical mechanisms. However, when the particles arrived in the dorsal tract they were no longer freely suspended but were carried toward the mouth in a sludge of low-viscosity mucus. Particles transported on the ordinary filaments of the plicate gills and on the filaments of the Mytilus edulis gill were transported to the ventral margins adhering to high-viscosity mucus and incorporated in a continuous mucus cord extending onto the mouth palps

According to these authors, their endoscopic observations showed that mucus plays an important role in the normal feeding process of undisturbed bivalves. But it is not quite clear what should be the role of secondarily embedding particles that are already entrapped in the surface currents on the gills by fluid mechanical forces. These forces are strong enough to prevent freely swimming flagellates from escaping from the currents (Jørgensen 1976). Various statements, however, suggest that Beninger, Ward and their coworkers underrate the particle-entrapping forces that act in the ciliary currents. It is thus stated that 'suspended particles on the principal filaments and in the dorsal tracts are protected by anatomical conduits that may prevent particle dispersion' (Ward et al. 1993). Further, feeding pathways on the scallop gills 'consist of semi-enclosed spaces (principal filaments, dorsal tracts, oral groove and peribuccal region, oesophagus), and this corresponds to the dominance of low-viscosity mixed secretion MPS on all the epithelia. However, the rejection pathway of the gills is tatally open (ordinary filament plicae and ventral tract) and this corresponds to the prevalence of high-viscosity acid MPS mucocytes and secretions in these regions' (Beninger et al. 1993).

Beninger et al. (1993) were, moreover, suspicious of our finding (see Jorgensen 1990) that captured particles are transported in suspension in the ciliary currents. They refer to the finding as 'a theoretical argument' that is based on low Reynolds numbers, which need to be ascertained in light of the recent demonstration that many benthic suspensiovores actually feed using structures operating at intermediate Reynold's [sic] numbers (Shimeta \& Jumars 1991).' But our descriptions of particle transport in the ciliary currents are based on observations, not theory. Moreover, Shimeta \& Jumars (1991) dealt with Reynolds numbers that apply to particle capture by encounters with cylindrical collectors, and which therefore are irrelevant in bivalve feeding for a decision of whether 'water currents can and do suffice to transport particles destined for ingestion' (Beninger et al. 1993).

Ward et al. (1993) considered findings made on preparations of bivalve gills that retain and transport particles in free suspension as artifacts. But they failed to consider the possibility that the manipulation involved in the endoscopy and insertion of a wedge to prevent closing of the valves itself stimulated mucus secretion on the pallial structures. Their observations do, however, suggest such a possibility. Beninger et al. (1992) thus also observed that scallops that were held at low particle concentrations ( 1 to 10 particles $\mu]^{-1}$ ) in the external medium eventually accumulated voluminous masses of mucus, which presumably ended as pseudofaeces. The authors interpreted the observations as suggesting that the high rate of mucus production 'was not induced by the particle concentrations per se, but rather by the scallop's capacity to ingest the particle slurry' (Beninger et al. 1992). But it is well established that the capacity of the digestive tract of suspension-feeding bivalves greatly exceeds the particle loads that may arise at low particle concentrations, even when the water-processing capacity is fully utilized. The production of pseudofaeces was observed after the scallops had been held at the low concentrations for several hours, consistent with a gradually increased stimulation of mucus secretion correlated with protracted endoscopy. The mucus gland system on the bivalve gills is very sensitive to mechanical stimulation (Jørgensen $1981 \mathrm{~b}$ ).

The observations of Beninger, Ward and their coworkers are thus consistent with the view that suspension feeding in bivalves is based on fluid-dynamic mechanisms independently of mucus. Small amounts of mucus may be carried in suspension in the surface currents to the mouth and ingested, whereas larger amounts of mucus are rejected as pseudofaeces (see Jørgensen 1990)

\section{PARTICLE SORTING}

Bivalves that feed on suspensions of plankton algae mixed with high concentrations of silt may sort algae from silt for preferential ingestion of the food particles (Kiorboe et al. 1980, Kiorboe \& Møhlenberg 1981, Newell \& Jordan 1983). Jørgensen (1981b, 1990) suggested that sorting depends upon the ability to simultaneously ingest particles in suspension and eliminate mucus-bound particles as pseudofaeces. Presumably, the chance of suspended particles on the gills in the surface currents being caught in mucus depends both on the amounts of mucus produced in response to particle load and on size, shape and surface properties of the particles. According to this hypothesis, particle sorting for ingestion or rejection is a physical process that is correlated with secretion of mucus for the production of pseudofaeces. The view still predominates, however, that particles can also be sorted according to 
quality as food. It has, moreover, been suggested that particle sorting may take place in the absence of pseudofaeces production. Sorting according to quality implies physiological regulation. There are, however, no obvious mechanisms for such sorting. The evidence for physiological regulation of particle sorting in suspension-feeding bivalves was therefore examined.

Newell et al. (1989) assessed possible particle selection in mussels Mytilus edulis, which were held in sea water from the collection sites, by determining the rates at which suspended phytoplankton cells and detritus particles were cleared from the sea water. Water samples were analyzed by flow cytometry which distinguished between fluorescent algal cells and nonfluorescent detritus particles. The analyzer also measured equivalent spherical diameter of the suspended particles. Experiments were made over 6 d on 4 to 6 individual mussels. In 5 of the 6 experiments there were significantly higher clearances of the fluorescent than of the non-fluorescent particles. In the experiment where the mean clearances did not differ, the percentage of fluorescent cells was only $16.4 \%$, compared with 20.9 to $33.7 \%$ in the other experiments. The data therefore indicated 'that a threshold for feeding selectivity occurs: when food quality estimated as percent fluorescent particles decreased below $20 \%$, the mussels lost their ability to selectively filter out phytoplankton from mixed particle assemblages' (Newell et al. 1989).

It was not mentioned that the mean clearances were low, varying from 20 to $70 \%$ of the clearances obtained in fully open mussels (Møhlenberg \& Riisgård 1979). Further analysis of the data recorded in Table 4 of Newell et al. (1989) showed that the clearances of nonfluorescent particles as a percentage of the fluorescent particles varied significantly with the clearance of the fluorescent particles, which presumably reflected the rates of filtration. The relationship between percentage retention of non-fluorescent particles and water filtration could be expressed by the equation $Y(\%)=$ $10.8 \times\left(\mathrm{l} \mathrm{h}^{-1} \mathrm{~g}^{-1}\right)+102$, indicating that retention of nonfluorescent particles decreased from about $80 \%$ at the lowest mean filtration rate to about $40 \%$ at the highest rate. The biological significance of this statistically significant relationship is obscure.

Newell et al. (1989) also examined the percentage of particles cleared in each of the size groups $3-5,5-8$, $8-10$ and $10-15 \mu \mathrm{m}$ for each of the experiments. The mussels cleared higher percentages of fluorescent particles than of non-fluorescent particles regardless of size, except in the experiment with very low filtration rates, and it was concluded that feeding selectivity appeared not to be size specific. But Fig. 5 in that paper shows that in all 5 experiments with selection, 5-8 $\mu \mathrm{m}$ non-fluorescent particles were cleared at higher rates than $8-10 \mu \mathrm{m}$ particles, which were again consistently cleared at higher rates than $10-15 \mu \mathrm{m}$ particles. There was thus a statistically significant decrease in retention efficiency of non-fluorescent particles of equivalent spherical diameter larger than 5-8 $\mu \mathrm{m}$. The figure indicates a decrease in retention from about $80 \%$ of 5-8 $\mu \mathrm{m}$ non-fluorescent particles to about $40 \%$ of $10-15 \mu \mathrm{m}$ particles. It thus remains to be explained by which mechanisms the water-processing mussel both varied its selectivity as a function of filtration rate and leaked detritus particles that increased with increasing particle size.

A subsequent study (Newell \& Shumway 1993) examined the effect of lower and higher than natural particle concentrations on selection. Low concentrations of about $10^{4}$ particles $\mathrm{ml}^{-1}$ were obtained by dilution with filtered sea water, and high concentrations of about $2 \times 10^{4}$ particles $\mathrm{ml}^{-1}$ by adding ashed mudflat silt or cultured algae. It was observed that mussels selected algae at the low particle concentrations but lost the ability to select at the high concentrations, according to the authors at about the pseudofaeces threshold where sorting should be transferred from the gills to the labial palps. It would seem, however, that at the low rates of water processing, the threshold load for pseudofaeces might not have been reached at concentrations of $2 \times 10^{4}$ particles $\mathrm{ml}^{-1}$ Moreover, the experiments in which significant sorting was absent were not strictly comparable to natural sea water containing high concentrations of non-fluorescent particles, because the high concentrations were obtained by adding mineral particles or algal cells.

Ward \& Targett (1989) tested effects of filtrate from algal cultures on filtration and ability of mussels Mytilus edulis to select and preferentially ingest particles exposed to the filtrates. The particles were $10 \mu \mathrm{m}$ spheres of silica, alumina, silane and polystyrene. Filtrates from Olisthodiscus luteus and Dunaliella tertiolecta significantly reduced the filtration rates, whereas filtrates from 4 other algal cultures were without effect. However, all filtration rates were low, corresponding to about $20 \%$ of the capacity as determined by Mohlenberg \& Riisgård (1979). Particles treated with filtrate from $O$. luteus showed negative selection indices, whereas the results varied with particles treated with filtrate from $D$. tertiolecta culture. With 3 types of spheres there was no selection, whereas silane particles showed negative selection index and polystyrene spheres showed positive selection. Such varying results were also obtained after treatment with filtrates of e.g. Isochrysis galbana, D. tertiolecta and Tetraselmis suecica. It was concluded that ' $M$. edulis can select particles based upon epiparticulate chemical compounds from microalgae' (Ward \& Targett 1989) The selection indices, however, seldom exceeded 0.10 , 
which corresponds to a $5 \%$ difference in proportion of particles in pseudofaeces (or faeces) from particles in suspension. The effects recorded thus appeared marginal and erratic.

Urban \& Kirchman (1992) examined the effect of kaolinite on selective feeding in the oyster Crassostrea virginica. The standard diet contained $10^{5}$ cells of Isochrysis galbana $\mathrm{ml}^{-1}$, corresponding to $1.8 \mathrm{mg}$ dry matter $\mathrm{l}^{-1}$, and $20 \mathrm{mg} \mathrm{l}^{-1}$ of rice starch. The algae were labelled with ${ }^{14} \mathrm{C}$ and the starch with ${ }^{3} \mathrm{H}$. The concentration of kaolinite was $20 \mathrm{mg} \mathrm{l}^{-1}$. Algae were selected over starch, moderately in the flow-through experiment and strongly in the static experiment. Addition of kaolinite practically abolished selection in the flowthrough experiment, and reduced the selection efficiency ratio from a maximum of 11.55 to a maximum of 4.72 in the static experiment. There was also selection against kaolinite in the flow-through experiment. According to these authors the ability of the oysters to differentiate between algae and starch of the same particle size may suggest sorting based on particle surface chemistry.

It is not clear why selection efficiencies differed in flow-through and static experiments and why the selection varied excessively in the static experiment.

The rates at which the oysters cleared the suspensions of algae and starch are not recorded, but calculations based on the data on specific activities and ingested and rejected algae and starch gave the unexpected result that the volumes of suspension cleared of algae consistently were substantially lower than the volumes cleared of starch. The clearances were low. Thus, in the flow-through experiment the clearance of starch amounted to about $19 \%$ of the water-processing capacity and algal clearance to about $2 \%$ of the capacity, as found by Riisgård (1988).

MacDonald \& Ward (1994) studied effects of food quality and particle selectivity in the scallop Placopecten magellanicus in a flow-through system supplied with unfiltered sea water and water enriched with cells of the diatom Chaetoceros muelleri or with diatoms and clay particles. They found that clearances increased with particulate chlorophyll a concentration of the seston from about $1 \mathrm{l} \mathrm{h}^{-1}$ to about $6 \mathrm{lh}^{-1}$ in a standard scallop of $15 \mathrm{~g}$ dry tissue mass. The scallops were able to select high-quality chlorophyll a containing particles. The results were interpreted in terms of optimal foraging theory. The scallops adjusted clearances to optimize uptake of phytoplankton and produced pseudofaeces even at low seston concentrations to improve the quality of the material ingested, thereby regulating ingestion and maximizing energy intake. However, under the experimental conditions, the scallops filtered the water at rates that seem to have been an order of magnitude below the capacity of the the fil- ter-pump (see below). It therefore seems unwarranted to draw conclusions concerning physiological control of feeding from the experiments.

Kamermans (1994) compared species composition of microalgae in the ambient water and in the stomachs of 5 intertidal deposit- and suspension-feeding bivalves: Macoma balthica, Scrobicularia plana, Cerastoderma edule, Mya arenaria and Mytilus edulis. Stomach contents showed high similarity with the surrounding water, consistent with lack of selection of food particles.

\section{RATES OF WATER PROCESSING IN NATURE}

It is usually assumed that filtration rates which are measured in fully open suspension-feeding bivalves in the laboratory also apply to undisturbed animals in nature. In recent years, however, this assumption has been questioned. Thus, Doering \& Oviatt (1986), in studies of gross sedimentation of ${ }^{14} \mathrm{C}$ labelled carbon in outdoor mesocosm tanks stocked with clams Mercenaria mercenaria, found that sedimentation was far below that expected by clams that processed the water at their full capacity. Gross sedimentation, however, agreed with rates based on data for clams that filtered natural suspensions of particulate matter. It was therefore concluded that filtering models founded on high rates of filtration exaggerated the role of suspension-feeding bivalves in controlling phytoplankton biomass. The rates of filtration of natural suspensions were, however, measured by placing individual clams in flow-through systems (Hilbert 1977, Doering \& Oviatt 1986). The clams were thus not acclimated, buried in their normal sediment, which may explain the low filtration rates obtained. They corresponded to about 20 to $30 \%$ of the pumping rates measured in clams that had established themselves in an aquarium, buried in a $20 \mathrm{~cm}$ deep layer of sand (Coughlan \& Ansell 1964). Also, Riisgård (1988) obtained relatively low pumping rates in $M$. mercenaria kept outside their substratum.

Filtration rates in the giant scallop Placopecten magellanicus have been measured or estimated both in the laboratory and in nature, but the results are not easily reconciled. MacDonald \& Thompson (1986) established the relationships between body size and rates at which scallops cleared natural sea water of suspended particles down to an equivalent spherical diameter of $2 \mu \mathrm{m}$. The particles counted thus extended down into the range where efficiency of retention rapidly declines in pectinids (Møhlenberg \& Riisgård 1978, Riisgård 1988, Cranford \& Grant 1990). Clearances therefore underestimated pumping rates. Clearances were low, ranging from 0.62 to $1.32 \mathrm{l} \mathrm{h}^{-1} \mathrm{~g}^{-1}$. 
Subsequent studies have been made on giant scallops of different sizes, but mass-specific clearances could be estimated from the allometric relationship established from the data of MacDonald \& Thompson (1986). Cranford \& Grant (1990) obtained mean clearances of algal cultures of about $4 \mathrm{I} \mathrm{h}^{-1} \mathrm{~g}^{-1}$, whereas suspensions of powdered kelp and of sediment were cleared at the low rate of about $1 \mathrm{l} \mathrm{h}^{-1} \mathrm{~g}^{-1}$. Grant \& Cranford (1991) confirmed the high clearances of algae, whereas suspensions of sediment and aged kelp were cleared at low rates. Further studies (Cranford \& Gordon 1992) compared the rates at which the scallops cleared pure suspensions of Tetraselmis suecica, algal suspensions mixed with bentonite, and natural seston from the habitat. The scallops filtered algal suspensions at a rate of about $4 \mathrm{l} \mathrm{h}^{-1} \mathrm{~g}^{-1}$. Admixture of small amounts of bentonite increased the rate to about $5 \mathrm{l} \mathrm{h}^{-1}$ $\mathrm{g}^{-1}$, whereas natural seston was filtered at the low rate of about $1.5 \mathrm{l} \mathrm{h}^{-1} \mathrm{~g}^{-1}$. The results were taken to confirm Doering \& Oviatt's (1986) observation that filtration rates measured in the laboratory in unnatural suspensions overestimate rates in nature.

The rates at which Placopecten magellanicus filtered suspensions of algae agreed with rates measured in other pectinids, e.g. 5 to $71 \mathrm{~h}^{-1} \mathrm{~g}^{-1}$ in Argopecten irradians (Chipman \& Hopkins 1954, Riisgård 1988) and 61 $\mathrm{h}^{-1} \mathrm{~g}^{-1}$ in Chlamys hastata (Bernard \& Noakes 1990). Notably, C. hastata pumped natural sea water at the rate of $8.7 \mathrm{l} \mathrm{h}^{-1} \mathrm{~g}^{-1}$, as measured with a thermistor flowmeter (Meyhöfer 1985). High rates of water pumping in pectinids, therefore, are not dependent upon the scallops filtering suspensions of algae or other unnatural suspensions. It is unclear why so many experiments have resulted in low filtration rates of natural seston.

Cranford \& Hargrave (1994) addressed the question of the rates at which Placopecten magellanicus process the ambient water in nature by a new approach in which scallops were exposed to natural particle fluxes, placed in a sediment trap that collected separate samples over a tidal cycle. Ingestion and absorption rates were calculated from the rates of biodeposition and proportions of absorbed and non-absorbed components of the seston and faeces. Filtration rates could not be determined, but the observed ingestion rates agreed with rates predicted from the low filtration rates recorded by MacDonald \& Thompson (1986).

The low ingestion rates were correlated with an exceptionally high mean absorption efficiency of ingested organic matter, which amounted to $78 \%$ (range 63 to $86 \%$ ). Mean chlorophyll a content of the organic matter was about $1 \mathrm{mg} \mathrm{g}^{-1}$, corresponding to about $10 \%$ phytoplankton at a content of $1 \%$ chlorophyll a. Cranford \& Grant (1990) found that Placopecten magellanicus absorbed algae with an efficiency of $\sim 70 \%$. The biodeposition experiments of Cranford \& Hargrave (1994) therefore suggested a digestibility of the organic detritus component that was at least as high as that of the phytoplankton.

In a commentary on filtration rates in nature, Powell et al. (1992) plotted reported measurements of filtration rates in suspension-feeding bivalves on size. They made the interesting observation that 2 distinct trends existed in the data, one predicting a filtration rate about 3 times higher than the other. The 2 trends were independent of species and technique used. There was no explanation for the bimodal nature of the filtration. rate versus size dependency, but these authors suggested a physiological switch as a potential explanation. The 2 levels of filtration rate were used in a model for population dynamics and energy flow in a population of oysters Crassostrea virginica. It was found that the model simulation agreed with measurements obtained from the field population only if the low filtration rates were used. Using the high rates resulted in too high productivity. It was therefore concluded that the 'low gear would appear to be the standard setting for feeding in the field. Perhaps the high gear is typically used for gamete release, for instance, or for clearing debris from the mantle cavity' (Powell et al. 1992).

Zurburg et al. (1994) studied the in situ uptake of suspended particulate material by oysters Crassostrea gigas and mussels Mytilus edulis by installing $10 \mathrm{~m}$ long plexiglass tunnels over the beds in the tidal zone in the Bay of Marennes-Oléron, France. The rate at which the water was cleared was calculated from the water flux through the tunnel and exponential decline in chlorophyll a concentration. In 2 experiments, performed in May, means and ranges in clearance throughout a tidal cycle were $7.66(0$ to 18.76$) \mathrm{l} \mathrm{h}^{-1} \mathrm{~g}^{-1}$ and $5.50(0$ to 16.78$) \mathrm{l} \mathrm{h}^{-1} \mathrm{~g}^{-1}$, respectively, in the oyster bed, and 2.47 (0 to 4.77$) \mathrm{l} \mathrm{h}^{-1} \mathrm{~g}^{-1}$ and 2.36 (0 to 5.22) l $\mathrm{h}^{-1} \mathrm{~g}^{-1}$ in the mussel bed. The oysters thus cleared the water at rates that corresponded to capacities measured in the laboratory, whereas mean rates in the mussels were only about one-third laboratory values.

Prins et al. (1994) employed the same experimental set-up to estimate rates at which a semi-natural mussel bed filtered water from the Dutch Wadden Sea, pumped through the plexiglass tunnel. Clearances varied seasonally, but mean values were consistently low, from 1 to $2 \mathrm{l} \mathrm{h}^{-1} \mathrm{~g}^{-1}$ It was concluded that '... clearance rates of undisturbed mussels under natural conditions may be much lower than the natural capacity' (Prins et al. 1994). However, the rates calculated are mean rates at which the mussels along the bed cleared the water flowing through the tunnel. These values would correspond to the pumping rates of the mussels only if all mussels along the bed had the exhalant apertures facing the open water But in a mussel bed, mus- 
sels aggregate and some of them will inhale water that has been more or less depleted of suspended matter by admixture of exhalant water from neighbouring mussels. The mean clearances measured therefore underestimate pumping rates. This underestimate should vary inversely with the density of the mussels. Notably, calculations based on data from from Tables $1 \& 5$ in Prins et al. (1994) indicated that there was a significant negative correlation between biomass of the mussel bed and clearance. In the experiments of Zurburg et al. (1994), the clearances calculated for the oysters presumably reflected the true pumping rates because of the negligible interference between individuals, in contrast to the situation in the mussel bed.

The experiments of Prins et al. (1994) and Zurburg et al. (1994) assessed the effects of the water-processing activity of mussel beds on the water flowing over the beds. They also contributed to elucidating the tolerance of mussels to suboptimal feeding conditions. The fact that the mussel bed persisted at a mean rate of clearing the ambient water of food particles which corresponded to one-fifth or less of the pumping capacity illustrates the range of food levels that are compatible with survival of mussels.

Prins et al. (1995) carried out a 4 wk experiment in May-June with mesocosms which were filled with water pumped directly from the Oosterschelde estuary (The Netherlands) and stocked with different densities of young mussels Mytilus edulis, with the objective to explore the relationships between mussel grazing and phytoplankton biomass, and to assess primary and secondary production. The mean rates at which the mussels cleared the water in the mesocosm tanks varied from $32 \%$ of the volume $\mathrm{d}^{-1}$ with a mussel population of 160 individuals to $5 \% \mathrm{~d}^{-1}$ with 20 mussels. The clearance values varied greatly during the course of the experiment with maximum rates obtained around Day 20 . The rates decreased strongly during the last 4 to $5 \mathrm{~d}$ of the experiment. The changes in clearance showed no significant relation with concentration or composition of the phytoplankton or other parameters describing particle concentrations. The individual clearance values did not vary with the number of mussels in the mesocosms, and the 20 mussels showed the lowest mean rates of clearing the water of phytoplankton. Mean rates were, however, consistently low in all the mesososms, seemingly on the order of one-fifth the capacity of the filter-pump. Prins et al. (1995) 'hypothesize that the variation in clearance rates during the experiments was the result of acclimation and of responses to changes in food concentration and quality.' This assumption seems inconsistent with the lack of relationship between clearance and phytoplankton composition and concentration, and with low growth rates despite high food concentrations. From the data on daily increases in body mass listed in Table 3 in Prins et al. (1995) it can be estimated that the specific growth rates varied from about 3 to $5 \% \mathrm{~d}^{-1}$ At optimal conditions, growth rates in mussels of the sizes used in the experiment, about $0.1 \mathrm{~g}$ body mass, amount to about $10 \% \mathrm{~d}^{-1}$ (see below).

The suggestion that suspension-feeding bivalves do not exploit the capacity of the filter-pump in nature and that this capacity should thus be larger than needed for normal growth and reproduction is inconsistent with more directly established relations between food concentration, filtration rate and growth. Thus, in mussels Mytilus edulis, exploitation of the potential for growth in the laboratory depended upon full utilization of the water-processing capacity at algal concentrations that corresponded to the highest levels in nature during the productive seasons of the year (Kiorboe et al. 1981, Riisgård \& Randløv 1981, Riisgård 1991, Clausen \& Riisgård 1996). Notably, at very high algal concentrations mussels grew at low rates, correlating with low rates of water filtration (Tenore et al. 1973, Winter 1974, 1976, Winter \& Langton 1976). Riisgård (1991) showed that mussels responded to concentrations of algae Rhodomonas baltica higher than $10^{4}$ cells $\mathrm{ml}^{-1}$ by reduced filtration rates that did not vary with algal concentrations from 1.5 to $4 \times 10^{4} \mathrm{cells} \mathrm{m}^{-1}$. It was suggested that suboptimal growth in the laboratory at very high algal concentrations and strongly reduced ventilation might be due to reduced metabolism, preventing exploitation of the growth potential despite high ingestion rates (Jorgensen et al, 1986, Riisgård 1991).

Richardson et al. (1984) compared growth rates in the laboratory with growth rates in nature in spat of the queen scallop Chlamys opercularis. Growth in nature was measured in spat cages and in the laboratory in a flow-through system. The scallops grew at normal rates at concentrations of Tetraselmis suecica of about 1 to $3.3 \times 10^{3}$ cells $\mathrm{ml}^{-1}$, whereas growth was significantly reduced at $13 \times 10^{3}$ cells $\mathrm{ml}^{-1}$. It was suggested that the lower growth rate at the high algal concentrations might be the result of both decreased filtration rate and assimilation efficiency. The finding is, however, also consistent with an effect of a low ventilation of the mantle cavity on the diffusive oxygen uptake (Jorgensen et al. 1986). The finding of the same growth rates in the spat cages in nature as at optimal concentrations of algal concentration in the laboratory indicated that the high rates of water processing in the fully open scallops also applied in nature.

Coutteau et al. (1994) studied the relations between algal ration, feeding and growth of juvenile Tapes philippinarum held in a recirculating system to which algal culture was added twice a day. In feeding experiments with Chaetoceros neopracile, filtration rates were constant at initial algal concentrations up to 
about $2 \times 10^{4}$ cells $\mathrm{ml}^{-1}$, but decreased to low levels at higher concentrations up to $10^{5}$ cells $\mathrm{ml}^{-1}$ Growth rates increased with increasing filtration rates, eventually to decrease again when daily rations resulted in decreasing filtration rates, despite continued high intake rates of algae. The pattern, therefore, is again consistent with an inhibitory effect on growth of low rates of ventilation of the mantle cavity.

\section{Ambient hydrodynamics}

A number of investigations have dealt with the role played by ambient hydrodynamic conditions on the function of the filter-pump and on feeding and growth in bivalves kept in recirculating flumes. Filtration rates were determined from the rates at which the bivalves cleared the water pumped through the flumes of natural seston and/or added algal cultures (Wildish \& Miyares 1990, Cole et al. 1992, Grizzle et al. 1992, Butman et al. 1994).

The most comprehensive studies were by Wildish and his coworkers on the combined effects of food concentration and flow velocity in the giant scallop Placopecten magellanicus. The rates at which suspensions of the alga Chroomonas salina were cleared increased with increasing velocity to maxima that increased with algal concentrations up to $10^{3}$ cells $\mathrm{ml}^{-1}$. At higher velocities, filtration rates again decreased (Wildish et al. 1992). Decreasing filtration rates were correlated with reduction of the area of the exhalant opening Valve opening also varied with algal concentration up to an optimum at $10^{3}$ cells $\mathrm{ml}^{-1}$ (Wildish \& Saulnier 1993).

The results were interpreted in terms of homeorheostat control of filtration/feeding in the giant scallop, the control of valve opening serving to optimize filtration responses (Wildish \& Saulnier 1993). It seems, however, doubtful whether the results of the experiments justify a hypothesis of physiological control of filtration and feeding in the scallops in response to environmental changes in flow velocity and seston concentration. The unimodal relationships found between filtration rate and flow velocity thus seemed to result from the experimental conditions. The initial increase in filtration rate with increasing flow velocity presumably reflected decreasing recirculation of water in the flume (Hildreth \& Crisp 1976 , Riisgard 1977), so that the rates of water pumping might actually have been independent of flow velocity up to the velocities that inhibited pumping rates. This interpretation is consistent with the finding of exhalant areas that did not vary with flow velocities up to $10 \mathrm{~cm} \mathrm{~s}^{-1}$. Moreover, the algal concentrations used, $10^{1}$ to $10^{5}$ cells $\mathrm{ml}^{-1}$ of sand-filtered sea water, were not representative of normal environmental seston composition and concentrations, and the finding of a maximum area of the exhalant opening at a concentration of $10^{3}$ algal cells $\mathrm{ml}^{-1}$ may be incidental

The size-specific rates at which the scallops cleared the algal suspensions are not stated. But the data on the area of the exhalant opening in the various experiments indicate that pumping rates may have been low even under the most optimal conditions. Thus, the area of the exhalant opening at the optimal concentration of $10^{3}$ cells $\mathrm{ml}^{-1}$ was about $38 \%$ of the maximum observed, compared with 20 to $23 \%$ at lower and higher concentrations, all measured at flow velocities of about 9 to $10 \mathrm{~cm} \mathrm{~s}^{-1}$ (Wildish \& Saulnier 1993, Table V). In the series of experiments on the relationship between flow velocity and area of the exhalant opening, in scallops fed at an algal concentration of $10^{4}$ cells $\mathrm{mi}^{-1}$, the mean areas amounted to $40-60 \%$ of the maximum at optimal flow velocities between about 7 and $10 \mathrm{~cm} \mathrm{~s}^{-1}$ (Wildish \& Saulnier 1993, Table II).

The suggestion that rate of water processing is not affected by the ambient hydrodynamic conditions up to critical flow velocities was supported by the finding that growth rates of giant scallops placed in flumes and supplied with unfiltered natural sea water were the same at flow velocities between about 1 and $7 \mathrm{~cm} \mathrm{~s}^{-1}$ (Wildish \& Saulnier 1992).

\section{PHYSIOLOGICAL CONTROL OF SUSPENSION FEEDING?}

Most current studies on feeding in suspension-feeding bivalves are based on the view that feeding is physiologically regulated to maximize net energy gains in response to variations in quantity and quality of suspended matter in the environment (Bayne et al. 1987, 1988, 1989, Hawkins \& Bayne 1992, Willows 1992). In order to explore the physiological processes in detail. Bayne et al. (1993) studied feeding in mussels Mytilus edulis held in trays with recirculating sea water to which were added different rations of algal culture and ashed silt. It was concluded that the responses to changes in the food environment comprised physiological adjustments which resulted in higher net rates of absorption than would have been predicted from the assumption of a non-compensatory feeding behaviour.

Fig. 1 in Bayne et al. (1993) indicates, however, that the mussels cleared the suspensions at rates that amounted to only about one-fifth of the capacity of the filter-pump (Møhlenberg \& Riisgård 1979). Moreover, clearances were substantially higher on Day 12 than on Day 2 of the experiment, independently of the composition of the suspended matter. The difference in 
results between acute and acclimated conditions may thus reflect degrees of acclimation to the experimental conditions rather than physiological adjustments.

Hawkins et al. (1996) continued the study of responses to composition of suspended matter in mussels, which were filtering sea water throughout natural tidal cycles in the Basin of Marennes-Oléron, France. Physiological processes of feeding were monitored in individual mussels which were placed in trays and fed sea water that was pumped from the site of acclimation

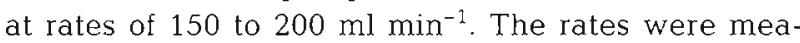
sured of water cleared, particulate matter retained (filtration rate) and pseudofaeces produced. Further parameters determined were net organic selection efficiency, net organic ingestion rate, net organic absorption rate, net absorption efficiency of filtered organics, net absorption efficiency of ingested organics, and organic content of ingested matter. The responses were related to total particulate matter in suspension and organic content, using multiple linear regression to establish any separate effects of quantity and quality of the suspended particulate matter.

The results were interpreted in terms of a 'remarkable short-term physiological plasticity whereby continuous interrelated adjustments combined to maintain rates of nutrient acquisition independent of short-term fluctuations in seston composition' (Hawkins et al. 1996).

More 'mechanistic' interpretations of the findings are, however, at hand. Thus, Figs. 3 \& 4 in Hawkins et al. (1996) indicate that it was the increasing rejection of filtered matter with increasing filtration rates that provided the basis for an increasing selection efficiency. Selection efficiency should also be expected to increase with increasing organic fraction of the seston because with increasing seston concentrations and pseudofaeces production, algal cells captured in the surface currents on the gill filaments are more likely to remain in suspension, and thus to be ingested, than are detritus particles (Jørgensen 1990). The faster increase in selection efficiency of seston with higher organic content is consistent with the higher content being found at neap tides when the seston concentrations were low but the chlorophyll $a$ and thus algal concentrations were high (Prou et al. 1994). Again, the integrated activity of the gill mechanisms may account for the organic selection without implying unknown physiological mechanisms.

A decreasing net absorption efficiency from ingested organics with decreasing organic content of ingested matter is consistent with low digestibility of ingested organic matter at low selection efficiency. As organic content of ingested matter increased with filtration rate and selection efficiency, net absorption efficiency from ingested organics increased with ingestion rate corre- lated with the increased digestibility of organic content to be expected at preferential selection of algae for ingestion.

Clearance increased linearly with seston concentrations from a mean value of about $1 \mathrm{l} \mathrm{h}^{-1}$ in a standard $1 \mathrm{~g}$ mussel at a concentration of $10 \mathrm{mg} \mathrm{l}^{-1}$ to $4.5 \mathrm{l} \mathrm{h}^{-1}$ at $100 \mathrm{mg} \mathrm{l}^{-1}$, or from about 10 to $60 \%$ of the capacity. It is not clear why in the experiment of Hawkins et al. (1996) clearances increased with seston concentration.

Navarro, Iglesias and their coworkers (Iglesias et al. 1992, Navarro et al. 1992, 1994) extended the studies of relations between quantity and quality of suspended matter on feeding in suspension-feeding bivalves to cockles Cerastoderma edule. In the studies of Navarro et al. (1992), the cockles were fed suspensions of surface sediment from the habitat mud-flat. In agreement with these authors' belief that the feeding rate is physiologically regulated, the rates at which the cockles cleared the suspensions were fitted into an exponential function of concentration of particulate matter. The tabulated data showed, however, that clearances, adjusted to $200 \mathrm{mg}$ cockles and measured after $2 \mathrm{~d}$ of acclimation, did not vary with particle concentration up to $9 \mathrm{mg} \mathrm{l}^{-1}$ of dry matter, and after $10 \mathrm{~d}$ acclimation there was no significant effect on clearance of seston concentrations up to the highest concentrations of about $17 \mathrm{mg} \mathrm{l}^{-1}$. The data thus did not warrant the conclusion that clearance decreased exponentially with particle concentration, which was the basis for the physiological interpretation of the data.

Subsequent works (Iglesias et al. 1992, Navarro et al. 1994) analysed the effect on feeding of enriching the organic content of silt by mixing with the alga Tetraselmis suecica. Again, clearances were related to particle concentrations through exponential equations, which according to these authors indicated a clear dependence of clearance on both particle concentration and composition of the suspended matter. Direct reading of the basic data provided a less clear picture. Thus, there was no significant difference between clearances at low and medium concentrations. The relationships between concentration and clearance thus depended upon low clearances at the high particle concentrations, amounting to about $20 \mathrm{mg} \mathrm{l}^{-1}$ silt. It may be questioned whether exponential equations based on 3 points in relationships between particle concentration and clearance are biologically meaningful.

The data presented in these 3 papers seem consistent with rates of water processing independent of particle concentration up to threshold levels that varied with the composition of the suspended particles, the level being lower the larger the proportion of algae in the mixture.

Stenton-Dozey \& Brown (1992) studied feeding by the rock-pool bivalve Venerupis corrugatus in the con- 
viction that a relationship established 'between clear ance rate and algal concentration in the laboratory provides little insight into the feeding dynamics of bivalves in their natural environments.' The studies were therefore made on clearance and retention efficiency of natural suspended particles in relation to tidal availability. It was found that at low tide the clams filtered out 5 to $9 \mu \mathrm{m}$ particles at maximum rates of 2.3 to $3.1 \mathrm{l} \mathrm{h}^{-1} \mathrm{~g}^{-1}$, whereas at high tide 8 to $13 \mu \mathrm{m}$ particles were cleared at the fastest rates ( 3.2 to $\left.4.4 \mathrm{l} \mathrm{h}^{-1} \mathrm{~g}^{-4}\right)$. It was concluded that ' $V$. corrugatus makes maximum use of a natural resource which changes rapidly in its quantity, quality and spectrum of particle sizes within the short period of a tidal cycle' by adjusting clearances and retention efficiencies to the tides (StentonDozey \& Brown 1992). The question of adjustments in the energy budget of the clam to tidal food availability was postponed to a subsequent paper (Stenton-Dozey \& Brown 1994).

This study confirmed the significantly higher clearance of water sampled at high tide than at low, and correlated with full extension of the siphons and open valves. Elevated growth efficiencies at high tide were realized not by changes in absorption efficiency, respiration or excretion, but by an increase in clearance, resulting in greater net organic ingestion at high tide.

In their 1992 paper, Stenton-Dozey \& Brown interpreted their results in terms of optimal foraging theory as applied to mussels by Bayne, Hawkins and their coworkers. In their 1994 paper the data are 'discussed with reference to the recent debate on whether production potential in a bivalve is determined by innate physiological processes (Hawkins et al. 1985, Bayne et al. 1989, Bayne \& Hawkins 1990) or simply by the rate at which the filtration mechanism processes particulate material (Jørgensen 1990)' (Stenton-Dozey \& Brown 1994)

Stenton-Dozey \& Brown (1994) ended their discussion by concluding that their data 'are insufficient to support convincingly either argument although indirect evidence is in favour of Jørgensen's approach. Nonetheless it is important to realise that in future research the filter-pump activity must be measured at full capacity to determine a bivalve's maximum growth potential before introducing variations in the environment (season, silt load, particle concentration) that may change this capacity.'

\section{'SCOPE FOR GROWTH' VS RATE OF GROWTH}

Most studies of matter and energy balance in filter feeding bivalves have focused on energy available for growth or the 'scope for growth', computed from measurements of filtration rate, assimilation efficiency and respiration rate. Estimated 'scope for growth' has been used extensively in studies of effects of environmental factors, including pollutants, on the physiology and energetics, particularly of the mussel Mytilus edulis (Bayne \& Widdows 1978, Widdows 1978, 1985a, b, 1993, Bayne \& Worrall 1980. Widdows et al. 1984, 1995, Anonymous 1987, Widdows \& Johnson 1988, Tedengren et al. 1990, Riisgård 1991).

Filtration rates are determined from the rates at which mussels clear suspensions of cultured algae or natural suspensions of particles. Measurements of assimilation efficiency are based on the assumption that all ingested inorganic particulate matter passes the digestive tract, so that assimilation of the organic components can be calculated from the change in proportion of organics from ingested particulate matter to faeces, as described by Conover (1966). Respiration rate is determined from the amounts of oxygen consumed.

The studies generally imply that the measured parameters in the energy equation may be extrapolated to nature and that the calculated 'scope for growth' reflects the energy balance under normal environmental conditions. Possible effects of the experimental conditions are thus disregarded, despite the fact that filterfeeding bivalves, including Mytilus edulis, are very sensitive to mechanical manipulation or changes in their environment. In order to estimate possible effects of the experimental conditions on the established energy budgets, calculated values for 'scope for growth' should therefore be compared with growth in nature, as related to the environmental conditions in the habitat.

It is well known that growth of mussels in nature varies strongly with season, with location within a mussel bed, with level occupied in the tidal zone, as well as with geographic location.

With respect to geographic variation in growth rate, it is of particular interest that this variation seems to be predominantly phenotypically determined (Widdows et al. 1984, Tedengren et al. 1990, Sterling \& Okumus 1994, 1995). The results of reciprocal transplantations of mussels from Baltic and North Sea populations are particularly striking. In the low salinity Baltic Sea $(7 \%)$, mussel growth is slow and the maximum size is only about one-third of that reached at the higher salinity $(28 \%)$ in the North Sea. After acclimatization, the reciprocally transplanted mussels, however, grew at rates similar to those of native mussels at each site (Kautsky et al. 1990) The mussels were suspended in the water at both sites and were thus feeding on the untaxed food sources. Fig. 3 in Kautsky et al. (1990) shows that in the North Sea, mean growth rates in shell length over the period July-October was about $9 \mathrm{~mm} \mathrm{mo}^{-1}$, both of the na- 
tive and transplanted mussels, compared with only $3.3 \mathrm{~mm} \mathrm{mo}^{-1}$ in the Baltic Sea.

A subsequent study (Tedengren et al. 1990) investigated to what extent the physiological differences between the populations from the Baltic Sea and the North Sea are environmentally induced or genetically determined. The physiological parameters measured were respiration and feeding rates, absorption efficiency and ammonia excretion from which data for 'scope for growth' was calculated.

In an experiment (Tedengren et al. 1990) with mussels 12 mo after the transplantation from the Baltic Sea to the North Sea, 'scope for growth' did not differ between native and transplanted mussels. But in a subsequent experiment with mussels 1 mo after transplantation, 'scope for growth' was only high in the native mussels, whereas the energy balance was negative in the transplanted mussels, correlating with low feeding rates and absorption efficiency. These authors suggested that the physiological differences between the 2 groups of transplanted mussels resulted from the different length of the acclimatization periods. This suggestion is, however, not supported by the data on growth during the acclimatization period. According to Table 1 in Tedengren et al. (1990), the mean length of the native mussels increased from $11.0 \pm 1.5 \mathrm{~mm}$ (SE) to $21.0 \pm 0.4 \mathrm{~mm}$, or $10 \mathrm{~mm}$, during the 1 mo of acclimatization, compared with an increase from $5.5 \pm 1.0$ to $20.7 \pm 0.5 \mathrm{~mm}$, or $15.2 \mathrm{~mm}$, in the mussels transplanted from the Baltic Sea. Moreover, the dry shell-free body mass was $50 \pm 3 \mathrm{mg}$ in the native mussels, compared with $61 \pm 9 \mathrm{mg}$ in the transplanted mussels. Body mass at the time of transplantation is not stated, but may be estimated from the relationship previously found between shell length and dry body mass of Baltic mussels (Kautsky 1982, Fig. 12). According to this relationship, the transplanted mussels grew at a rate of 12 to $13 \%$ $\mathrm{d}^{-1}$, compared with $5.5 \% \mathrm{~d}^{-1}$ in the native mussels. The results were thus consistent with catch-up growth in growth-retarded mussels. Catch-up growth in mussels has previously been indicated (Jørgensen 1992).

There were substantial genetic differences between the Baltic and the North Sea mussels, but these differences seemed to be maintained by differential selection correlated with the different salinities in the 2 environments, a selection that did not affect the potential for growth (Johannesson et al. 1990)

The inherent potential for growth may thus be about the same in the different north European populations of mussels, so that actual growth rates reflect environmental conditions. In order to assess possible effects of environmental conditions, this potential for growth should therefore be known.

Clausen \& Riisgård (1996) established the relationship between food concentration and growth in 25 to
$30 \mathrm{~mm}$ long Mytilus edulis of about $100 \mathrm{mg}$ body mass. The mussels were fed for 9 to $14 \mathrm{~d}$ on pure suspensions of Rhodomonas cells, or algae plus silt in concentrations of about $5 \mathrm{mg} \mathrm{l}^{-1}$. The specific growth rate increased with increasing food concontration to a maximum value of about $9.5 \% \mathrm{~d}^{-1}$, irrespective of the relatively high concentrations of silt added to the water The concentration of algal cells needed for maximum growth was about 4400 cells $\mathrm{ml}^{-1}$ or $0.32 \mathrm{mg}$ organic matter $1^{-1}$ Also, high algal concentrations of about 12000 cells $\mathrm{ml}^{-1}$, or $0.88 \mathrm{mg}$ organic matter ${ }^{-1}$, resulted in full exploitation of the growth potential, correlated with high ingestion rates. But filtration rates and presumably also assimilation efficiencies were reduced (Riisgård 1991, Clausen \& Riisgård 1996).

The results corroborated earlier findings of growth in Mytilus edulis under optimal conditions (Kiørboe et al. 1981, Riisgård \& Poulsen 1981, Riisgård \& Randløv 1981, Hamburger et al. 1983). Specific growth rates of about $10 \% \mathrm{~d}^{-1}$ applied to mussels of about $0.1 \mathrm{~g}$ body mass, but rates of about $2 \% \mathrm{~d}^{-1}$ were indicated even in $1 \mathrm{~g}$ mussels (Hamburger et al. 1983). Specific growth rates of these orders may therefore be used to assess to which extent the inherent potentials for growth in mussels have been exploited under experimental conditions or in nature.

Clausen \& Riisgård (1996) compared the growth of mussels in nature with the results obtained in the laboratory by transferring mussels to net bags, which were suspended in a Danish fjord for 17 to $28 \mathrm{~d}$ during May and June. The mean specific growth rate was about $6 \% \mathrm{~d}^{-1}$ in the 3 experiments performed. The concentrations of chlorophyll $a$ in the water varied between about 2 and $7 \mu \mathrm{g} \mathrm{I}^{-1}$, corresponding to concentrations of Rhodomonas cells between about 2000 and 6000 cells $\mathrm{ml}^{-1}$, or 0.15 to $0.44 \mathrm{mg}$ organic matter $\mathrm{I}^{-1}$. The median value of chlorophyll a concentration in 27 Danish fjords and coastal waters during the productive seasons of the year was $5.1 \mathrm{\mu g} \mathrm{I}^{-1}$ (Sand-Jensen et al. 1994), corresponding to 6400 Rhodomonas cells $\mathrm{ml}^{-1}$, or $0.46 \mathrm{mg}$ organic matter $\mathrm{l}^{-1}$. Phytoplankton concentrations in Danish waters thus seem to approach concentrations needed for the exploitation of the growth potential in mussels.

'Scope for growth', as calculated from physiological parameters, may be compared with directly determined growth in mass when both are expressed in terms of the mass specific growth rate. In the following. values for 'scope for growth' in mussels are converted to specific growth rates by using the conversion factor of $4.9 \mathrm{cal}$, or $20.5 \mathrm{~J}$, per $\mathrm{mg}$ dry body mass (Dare \& Edwards 1975).

Widdows et al. (1995), in a physiological and toxicological investigation of mussels from 26 coastal sites from the Shetland Islands to the Thames estuary (UK), 
calculated 'scope for growth' from the energy balance established in mussels of about $0.5 \mathrm{~g}$ dry body mass, which were placed in clean off-shore sea water with culture of the alga Phaeodactylum tricornutum added to a concentration of $9000 \mathrm{cells} \mathrm{m}^{-1}$. At the unpolluted northern sites, 'scope for growth' corresponded to growth rates up to $2.7 \% \mathrm{~d}^{-1}$, the rates declining towards the south to about $0.5 \% \mathrm{~d}^{-1}$. The decline in growth rates was correlated with a decrease in clearances from about $7-8$ to about $2-4 l \mathrm{~h}^{-1} \mathrm{~g}^{-1}$.

Other studies showed that the physiological responses of mussels that were transplanted $12 \mathrm{mo}$ previously from a site with a high growth rate to a site with a low growth rate did not differ from the native mussels, confirming that the different performances of the mussels reflected environmental rather than genetic differences.

In other transplantation experiments, mussels were collected from a site (Exmouth, S. Devon, UK) with the low 'scope for growth' of $8.55 \pm 1.66$ (mean $\pm 95 \% \mathrm{CI}$ ) $\mathrm{J} \mathrm{h}^{-1} \mathrm{~g}^{-1}$, corresponding to a growth rate of $1.0 \% \mathrm{~d}^{-1}$. These mussels were placed in wire mesh cages and kept for 2 wk in clean sea water, to allow byssal attachments to form before the cages were suspended from 10 off-shore light vessels in the North Sea. After $6 \mathrm{wk}$ exposure to the new environment, the cages were collected and physiological measurements were made under the standard conditions. There was little effect of the transplantation on the performances, and mean values of 'scope for growth' varied from about 89 to about $14.9 \mathrm{~J} \mathrm{~h}^{-1} \mathrm{~g}^{-1}$, corresponding to growth rates of about 1.0 to $1.7 \% \mathrm{~d}^{-1}$. It was thus indicated that 2 mo of exposure to an unpolluted environment did not normalize feeding and growth in the mussels.

Calculated growth rates of the native and transplanted Exmouth mussels were relatively high, correlating with low respiration rates. In the mussels from the 26 coastal sites, the mean respiration rates varied from 15.1 to $27.2 \mu \mathrm{mol} \mathrm{O} \mathrm{h}^{-1} \mathrm{~g}^{-1}$ with no obvious correlation with the pollution gradient from north to south. In native Exmouth mussels, the mean rate was $11.7 \mu \mathrm{mol} \mathrm{O} \mathrm{O}_{2} \mathrm{~h}^{-1} \mathrm{~g}^{-1}$, whereas the mean rate of the mussels transplanted to the light vessels varied from 8.7 to $10.7 \mu \mathrm{mol} \mathrm{O} \mathrm{h}^{-1} \mathrm{~g}^{-1}$. Widdows et al. (1995) did not comment upon this difference in levels of Exmouth mussels and mussels from all other sites.

Neither did they comment upon their finding of low rates of both respiration and water filtration 2 mo after transplantation to the off-shore unpolluted environments. In an earlier experiment, where mussels were reciprocally transplanted between 2 environments, the Tamar estuary Lynher in Devon and the Swansea dock in south Wales (UK), the transplanted mussels cleared the water from the new location at rates similar to those of the natives when clearances were first measured,
$7 \mathrm{wk}$ after transplantation. During the experimental period from January to June 1978, mussels cleared Swansea dock water at rates of about 1 to $2 \mathrm{l} \mathrm{h}^{-1} \mathrm{~g}^{-1}$ and Tamar river water at about $4.5 \mathrm{l} \mathrm{h}^{-1} \mathrm{~g}^{-1}$ (Widdows et al. 1984).

Annual variation in physiological performances in mussels from the Lynher population were also studied in earlier field experiments, from 1973 to 1975 (Bayne \& Widdows 1978). During this period, mean clearances of Tamar river water varied between about 1.3 and $2.6 \mathrm{l} \mathrm{h}^{-1} \mathrm{~g}^{-1}$. It is not clear why the mean filtration rates recorded were less than half the rates recorded in 1978 (Widdows et al. 1984). In both series of experiments, the mussels were of the same size, about $1 \mathrm{~g}$ dry body mass. Corresponding to the different levels of filtration rates, growth rates, calculated from the values for 'scope for growth', amounted to about $3.0 \% \mathrm{~d}^{-1}$ in June 1978 compared with a mean growth rate of about $1.4 \% \mathrm{~d}^{-1}$ between May and August in 1973 and 1974.

Mussels from the Lynher estuary also cleared suspensions of algae at low rates. Thus, in the experiments of Hawkins et al. (1989), where the mussels were fed the alga Phaeodactylum tricornutum at concentrations of between 2000 and 5000 cells ml ${ }^{-1}$, 'scope for growth' was mostly negative, and ingestion rates suggested that the algae were cleared at rates of the order of $0.7 \mathrm{I} \mathrm{h}^{-1} \mathrm{~g}^{-i}$, assuming that 3000 cells were equivalent to $0.07 \mu \mathrm{g}$ dry matter (Widdows 1978).

In the investigation from 1990 and 1991 of relationships between environment and physiological performances in North Sea mussels (Widdows et al. 1995), mussels from the Lynher population cleared the algal suspensions at rates that corresponded to about $40 \%$ of the rates measured in a population from an unpolluted site in the Shetland Islands (UK). The values calculated for 'scope for growth' indicated specific growth rates of about 0.8 and $2.8 \% \mathrm{~d}^{-1}$, respectively, in mussels from the 2 sites (Widdows et al. 1995, Figs. 3 \& 4).

Navarro et al. (1991) estimated 'scope for growth' in mussels Mytilus galloprovincialis from cultivation rafts in the Ria de Arosa in Galicia, Spain. The site is known for the high rates of growth of the mussels attached to the ropes which are suspended from the rafts (Peréz \& Román 1979). The physiological measurements were carried out according to Widdows (1985a) in individual chambers with running water from the location where the mussels were collected. Values of 'scope for growth' were higher when water was pumped from the front of the rafts than when pumped from the back, correlating with the reduced food content due to the filtering activity of the mussels. However, the calculated values tended to be low, even in April. Estimated rates of growth varied from negligible to about $2.1 \%$ $\mathrm{d}^{-1}$, with a mean value in April of $1.2 \% \mathrm{~d}^{-1}$ These calculated growth rates may be compared with actual 
growth rates on the ropes. From the data presented by Peréz \& Román (1979, Tables 11 \& 13), it appears that mean dry body mass increased from $0.158 \mathrm{~g}$ in April to $3.56 \mathrm{~g}$ in August in mussels cultivated on rafts at Las Sinas, and $2.73 \mathrm{~g}$ on the rafts at Meloja (Spain). The specific growth rates at the 2 sites thus corresponded to daily mean rates of 2.5 and $2.3 \%$, respectively, during spring and summer.

The low rates that were indicated by the physiological measurements seemed primarily to be due to the low rates at which the individual mussel filtered the water. The experiments of Navarro et al. (1991) were performed within a few hours after the mussels had been detached from the rope by scissors. In field experiments, Vismann (1990) found that mussels that were left undisturbed for $6 \mathrm{wk}$ prior to measurements filtered the ambient water at about twice the rate of those mussels that had their byssus cut $1 \mathrm{~h}$ before measurements.

Low values of 'scope for growth' may result from experimental conditions that are incompatible with utilization of the capacity of the filter-pump. Possible effects of the experimental conditions on the rate of water pumping should therefore be known before growth rates that are indicated from 'scope for growth' can be extrapolated to the habitat which the experiment intends to simulate.

Acknowledgements. I thank Dr H. U. Riisgård for valuable comments and suggestions.

\section{LITERATURE CITED}

Anonymous (1987) Bilan énergétique chez les mollusques bivalves: terminologie et méthodologie. IFREMER, La Tremblade

Bayne BL, Hawkins AJS (1990) Filter feeding in bivalve molluscs: controls on energy balance. In: Mellinger J, Truchot JP, Lahlou B (eds) Animal nutrition and transport processes, Vol 1, Nutrition in wild and domestic animals Karger, Basel, p 70-83

Bayne BL, Hawkins AJS, Navarro E (1987) Feeding and digestion by the mussel Mytilis edulis L. (Bivalvia: Mollusca) in mixtures of silt and algal cells at low concentrations. J Exp Mar Biol Ecol 111:1-22

Bayne BL, Hawkins AJS, Navarro E (1988) Feeding and digestion in suspension-feeding bivalve molluscs: the relevance of physiological compensations. Am Zool 28: $147-154$

Bayne BL, Hawkins AJS, Navarro E, Iglesias JIP (1989) Effects of seston concentration on feeding, digestion and growth in the mussel Mytilus edulis. Mar Ecol Prog Ser 55: $47-54$

Bayne BL, Iglesias JIP, Hawkins AJS, Navarro E, Heral M. Deslous-Paoli JM (1993) Feeding behaviour of the mussel, Mytilus edulis: responses to variations in quantity and organic content of the seston. J Mar Biol Ass UK 73: 813-829

Bayne BL, Widdows J (1978) The physiological ecology of two populations of Mytilus edulis L. Oecologia 37:137-162
Bayne BL, Worrall CM (1980) Growth and production of mussels Mytilus edulis from two populations. Mar Ecol Prog Ser 3:317-328

Beninger PG, Auffrett M, Le Pennec M (1990a) Peribuccal organs of Placopecten magellanicus and Chlamys varia (Mollusca: Bivalvia): structure, ultrastructure and implications for feeding. I. The labial palps. Mar Biol 107 $215-223$

Beninger PG, Le Pennec M, Auffrett M (1990b) Peribuccal organs of Placopecten magellanicus and Chlamys varia (Mollusca: Bivalvia): structure, ultrastructure and implications for feeding. II. The lips. Mar Biol 107:225-233

Beninger PG, Le Pennec M, Donval A (1991) Mode of particle ingestion in five species of suspension-feeding bivalve molluscs. Mar Biol 108:255-261

Beninger PG, Le Pennec M, Salaün M (1988) New observations of the gills of Placopecten magellanicus (Mollusca: Bivalvia), and implications for nutrition. I. General anatomy and surface microanatomy. Mar Biol 98:61-70

Beninger PG, St-Jean S, Poussart Y, Ward JE (1993) Gill function and mucocyte distribution in Placopecten magellanicus and Mytilus edulis (Mollusca: Bivalvia): the role of mucus in particle transport. Mar Ecol Prog Ser 98:275-282

Beninger PG, Ward JE, MacDonald BA, Thompson RJ (1992) Gill function and particle transport in PJacopecten magellanicus (Mollusca: Bivalvia) as revealed using video endoscopy. Mar Biol 114:281-288

Bernard FR, Noakes DJ (1990) Pumping rates, water pressures, and oxygen use in eight species of marine bivalve molluscs from British Columbia. Can J Fish Aquat Sci 47 : $1302-1306$

Butman CA, Fréchette M, Geyer WR, Starczak VR (1994) Flume experiments on food supply to the blue mussel Mytilus edulis L as a function of boundary-layer flow. Limnol Oceanogr 39:1755-1768

Chipman WA, Hopkins JG (1954) Water filtration by the bay scallop, Pecten irradians, as observed with the use of radioactive plankton. Biol Bull Mar Biol Lab, Woods Hole 107:90-91

Clausen I, Riisgård HU (1996) Growth, filtration and respiration in the blue mussel, Mytilus edulis: no evidence for physiological regulation of the filter-pump. Mar Ecol Prog Ser (in press)

Cole BE, Thompson JK, Cloern JE (1992) Measurement of filtration rates by infaunal bivalves in a recirculating flume. Mar Biol 113:219-225

Conover RJ (1966) Assimilation of organic matter by zooplankton. Limnol Oceanogr 11:338-345

Coughlan J, Ansell AD (1964) A direct method for determining the pumping rate of siphonate bivalves. J Cons Int Explor Mer 29:205-213

Coutteau P, Curé K, Sorgeloos P (1994) Effect of algal ration on feeding and growth of juvenile Manila clam Tapes philippinarum (Adams and Reeve). J Shellfish Res 13: 47-55

Cranford PJ, Gordon DC Jr (1992) The influence of dilute clay suspensions on sea scallop (Placopecten magellanicus) feeding activity and tissue growth. Neth J Sea Res 30: $107-120$

Cranford PJ, Grant J (1990) Particle clearance and absorption of phytoplankton and detritus by the sea scallop Placopecten magellanicus (Gmelin). J Exp Mar Biol Ecol 137: 105-121

Cranford PJ, Hargrave BT (1994) In situ time-series measurement of ingestion and absorption rates of suspension-feeding bivalves: Placopecten magellanicus. Limnol Oceanogr 39:730-738 
Dare PJ, Edwards DB (1975) Seasonal changes in flesh weight and biochernical composition of mussels (Mytilus edulis L.) in the Conwy Estuary, North Wales. J Exp Mar Biol Ecol 18:89-97

Doering PH, Oviatt CA (1986) Application of filtration rate models to field populations of bivalves: an assessment using experimental mesocosms. Mar Ecol Prog Ser 31: $265-275$

Dral ADG (1967) The movement of the latero-frontal cilia and the mechanism of particle retention in the mussel (Mytilus edulis L.). Neth J Sea Res 3:391-422

Grant J, Cranford PJ (1991) Carbon and nitrogen scope for growth as a function of diet in the sea scallop Placopecten magellanicus. J Mar Biol Ass UK 71:437-450

Grizzle RE, Langan R, Howell WH (1992) Growth responses of suspension-feeding bivalve molluscs to changes in water flow: differences between siphonate and nonsiphonate taxa. J Exp Mar Biol Ecol 162:213-228

Hamburger K, Møhlenberg F, Randløv A, Riisgård HU (1983) Size, oxygen consumption and growth in the mussel Mytilus edulis. Mar Biol 75:303-306

Hawkins AJS, Bayne BL (1992) Physiological interrelations, and the regulation of production. In: Gosling $E$ (ed) The mussel Mytilus: ecology, physiology, genetics and culture. Elsevier, Amsterdam, p 171-222

Hawkins AJS, Bayne BL, Day AJ, Rusin J, Worrall CM (1989) Genotype-dependent interrelations between metabolism, protein metabolism and fitness. In: Ryland JS, Tyler PA (eds) Reproduction, genetics and distribution of marine organism. Olsen \& Olsen, Fredensborg, p 283-292

Hawkins AJS, Smith RFM, Bayne BL, Héral M (1996) Novel observations underlying the fast growth of suspension feeding shellfish in turbid environments: Mytilus edulis L. Mar Ecol Prog Ser 131:179-190

Hilbert CJ (1.977) Energy relations of the bivalve Mercenaria mercenaria on an intertidal mudflat. Mar Biol 44:77-84

Hildreth DI. Crisp DJ (1976) A corrected formula for calculation of filtration rate of bivalve molluscs in an experimental flowing system. J Mar Biol Ass UK 56:111-121

Iglesıas JIP, Navarro E, Jorna PA, Armentia I (1992) Feeding, particle selection and absorption in cockles Cerastoderma edule (L.) exposed to variable conditions of food concentration and quality. J Exp Mar Biol Ecol 162:177-198

Johannesson K, Kautsky N, Tedengren M (1990) Genotypic and phenotypic difterences between Baltic and North Sea populations of Mytilus edulis evaluated through reciprocal transplantations. II. Genetic variation. Mar Ecol Prog Ser 59:211-219

Jorgensen CB (1976) Comparative studies on the function of gills in suspension feering bival"es, with special refrrence to effects of serotonin. Biol Bull Bar Biol Lab, Woods Hole 151:331-343

Jørgensen CB (1981a) A hydromechanical principle for particle retention in Mytilus edulis and other ciliary suspension feeders. Mar Biol 61:277-282

Jorgensen CB (1981b) Feeding and cleaning mechanisms in the suspension feeding bivalve Mytilus edulis. Mar Biol 65:159-163

Jørgensen CB (1990) Bivalve filter feeding: hydrodynamics, bioenergetics, physiology and ecology. Olsen \& Olsen, Fredensborg, Denmark

Jergensen CB (1992) Heterozygosity and energetics of growth in suspension-feeding bivalves: a re-examination. Ophelia 36:171-186

Jorgensen CB, Larsen PS, Mohlenberg F, Riisgard HU (1988) The bivalve pump: properties and modelling. Mar Ecol Prog Ser 45:205-216
Jorgensen CB, Møhlenberg F, Sten-Knudsen O (1986) Nature of relation between ventilation and oxygen consumption in filter feeders. Mar Ecol Prog Ser 29:73-88

Kamermans P (1994) Similarities in food source and timing of feeding in deposit-and suspension-feeding bivalves. Mar Ecol Prog Ser 104:63-75

Kautsky N (1982) Growth and size structure in a Baltic Mytilus edulis population. Mar Biol 68:117-133

Kautsky N, Johannesson K, Tedengren M. (1990) Genotypic and phenotypic differences between Baltic and North Sea populations of Mytilus edulis evaluated through reciprocal transplantations. I. Growth and morphology. Mar Ecol Prog Ser 59:203-210

Kiørboe T, Møhlenberg F (1981) Particle selection in suspension-feeding bivalves. Mar Ecol Prog Ser 5:291-296

Kiørboe T, Møhlenberg F, Nøhr O (1980) Feeding, particle selection and carbon absorption in Mytilus edulis in different mixtures of algae and resuspended bottom material. Ophelia 19:193-205

Kiørboe T, Møhlenberg F, Nøhr O (1981) Effect of suspended bottom material on growth and energetics in Mytilus edulis. Mar Biol 61:283-288

Kreeger DA, Hawkins AJS, Bayne BL, Lowe DM (1995) Seasonal variation in the relative utilization of dietary protein for enurgy and biosynthesis by the mussel Mytilus edulis. Mar Ecol Prog Ser 126:177-184

MacDonald BA, Thompson RJ (1986) Influence of temperature and food availability on the ecological energetics of the giant scallop Placopecten magellanicus. 3. Physiological ecology, the gametogenetic cycle and scope for growth. Mar Biol 93:37-48

MacDonald BA. Ward JE (1994) Variation in food quality and particle stelectivity in the sea scallop Placopecten magellanicus (Mollusca: Bivalvia). Mar Ecol Prog Ser 108: 251-264

Meyhöfer E (1985) Comparative pumping rates in suspension-feeding bivalves. Mar Biol 85:137-142

Møhlenberg F, Riisgärd HU (1978) Efficiency of particle retention in 13 species of suspension feeding bivalves. Ophelia 17:239-246

Mohlenberg F, Riisgäd HU (1979) Filtration rate, using a new indirect technique, in thirteen species of suspension-feeding bivalves. Mar Biol 54:143-148

Moore HJ (1971) The structure of the latero-frontal cirri on the gills of certain lamellibranch molluscs and their role in suspension feeding. Mar Biol 11:23-27

Navarro E, Iglesias JIP (1993) Infaunal filter-feeding bivalves and the physiological response to short-term fluctuations in food availability and composition. In: Damo: RF (ed) Bivalve filter feeders in estuarine and coastal ccosystem processes. NATO ASI Series, Vol G 33, Springer-Verlag, Berlin, p 25-56

Navarro E, Iglesias JIP, Ortega MM (1992) Natural sediment as a food source for the cockle Cerastoderma edule (L.): effect of variable particle concentration on feeding, digestion and scope for growth. J Exp Mar Biol Ecol 156:69-87

Navarro E. Iglesias JIP, Ortega MM, Larretxea X (1994) The basis for a functional response to variable food quantity and quality in cockles Cerastoderma edule (Bivalvia, Cardiidae). Physiol Zool 67:468-496

Navarro E. Iglesias JIP, Perez Camacho A, Labarta U, Beiras R (1991) The physiological energetics of mussels (Mytilus galloprovincialis $\mathrm{Lmk}$ ) from different cultivation rafts in the Ria de Arosa (Galicia, N. W. Spaın). Aquaculture 94: $197-212$

Newell CR, Shumway SE (1993) Grazing of natural particulates by bivalve molluscs: a spatial and temporal perspec- 
tive. In: Dame RF (ed) Bivalve filter feeders. NATO ASI Series, Vol G 33, Springer-Verlag, Berlin, p 85-148

Newell CR, Shumway SE, Cucci TL, Selvin R (1989) The effects of natural seston particle size and type on feeding rates, feeding selectivity and food resource availability for the mussel Mytilus edulis Linnaeus, 1758 at bottom culture sites in Manne. J Shellfish Res 8:187-196

Newell RIE, Jordan SJ (1983) Preferential ingestion of organic material by the American oyster Crassostrea virginica. Mar Ecol Prog Ser 13:47-53

Nielsen NF, Larsen PS, Riisgård HU, Jorgensen CB (1993) Fluid motion and particle retention in the gill of Mytilus edulis: video recordings and numerical modelling. Mar Biol 116:61-71

Owen G (1974) Studies of the gill of Mytilus edulis: the eulatero-frontal cirri. Proc R Soc Lond Ser B 187:83-91

Pérez A, Román G (1979) Estudio del mejillón y de su epifauna en los cultivos flotantes de la Ria de Arosa. II. Crecimiento, mortalidad y produccion del mejillón. Boln Inst Esp Oceanogr 5:23-41

Powell EN, Hofmann EE, Klinck JM, Ray SM (1992) Modeling oyster populations. A commentary on filtration rate. Is faster always better? J Shellfish Res 11:387-398

Prins TC, Dankers N, Smaal AC (1994) Seasonal variation in the filtration rates of a semi-natural mussel bed in relation to seston composition. J Exp Mar Biol Ecol 176:69-86

Prins TC, Escavarage V. Smaal AC, Peeters JCH (1995) Nutrient cycling and phytoplankton dynamics in relation to mussel grazing in a mesocosm experiment. Ophelia 41:289-315

Prou J, Barillé L, Héral M, Ratiscol G, Soletchnik P, Bougrier S, Razet D, Geairon P (1994) Influence du cycle semidiurne et vives-eaux mortes-eaux sur la disponıbilité du matériel particulaire et son utilisation par une population de Mytilus edulis. Haliotis 23:139-153

Richardson CA, Gale GF, Venn TJ (1984) The effect of iron ore suspensions and food on the shell growth rates and tissue weights of queen scallops Clamys opercularss held in the laboratory. Mar Environ Res 13:1-31

Riisgărd HU (1977) On measurements of the filtration rates of suspension feeding bivalves in a flow system. Ophelia 16: $167-173$

Risgàrd HU (1988) Efficiency of particle retention and filtration rate in 6 species of northeast American bivalves. Mar Ecol Prog Ser 45:217-223

Riisgård HU (1991) Filtratıon rate and growth in the blue mussel, Mytilus edulis Linnaeus, 1758: dependence on algal concentration. J Shellfish Res 10:9-35

Riisgård HU, Nielsen NF, Larsen PS (1996) Particle capture in the mussel Mytilus edulis: role of latero-frontal cirri. Mar Biol (in press)

Riisgård HU, Poulsen E (1981) Growth of Mytilus edulis in net bags transferred to different localities in a eutrophicated Danish fjord. Mar Pollut Bull 12:272-276

Riisgård HU, Randløv A (1981) Energy budgets, growth and filtration rates in Mytilus edulis at different algal concentrations. Mar Biol 61:227-234

Sand-Jensen K, Nielsen SL, Borum J, Geertz-Hansen O (1994) Fytoplankton- og makrofytudvikling i danske kystområder. Havforskning fra Miljostyrelsen Nr 30. Miljoministeriet, Miljøstyrelsen

Shimeta J, Jumars PA (1991) Physical mechanisms and rates of particle capture by suspension-feeders. Oceanogr Mar Biol A Rev 29:191-257

Stenton-Dozey JME, Brown AC (1992) Clearance and retention efficiency of natural suspended particles by the rockpool bivalve Venerupis corrugatus in relation to tidal availability. Mar Ecol Prog Ser 82:175-186
Stenton-Dozey JME, Brown AC (1994) Short-term changes in the energy balance of Venerupis corrugatus (Bivalvia) in relation to tidal availability of natural suspended particles Mar Ecol Prog Ser 103:57-64

Stirling HP, Okumus I (1994) Growth, mortality and shell morphology of cultivated mussel (Mythlus edulis) stocks crossplanted between two Scottish sea lochs. Mar Biol 119 $115-123$

Sturling HP, Okumus I (1995) Growth and production of mussels (Mytlus edulis L.) suspended at salmon cages and shellfish farms in two Scottish sea lochs. Aquaculture 134: 193-210

Tedengren M, André C, Johannesson K, Kautsky N (1990) Genotypic and phenotypic differences between Baltic and North Sea populations of Mytilus edulis evaluated through reciprocal transplantations. III. Physiology. Mar Ecol Prog Ser 59:221-227

Tenore KR, Goldman JC, Clarner JP (1973) The food chain dynamics of the oyster, clam, and mussel in an aquaculture food chain. J Exp Mar Biol Ecol 12:157-165

Urban ER Jr, Kirchman DL (1992) Effect of kaolinite clay on feeding activity of the eastern oyster Crassostrea virginica (Gmelin). J Exp Mar Biol Ecol 160:47-60

Vismann B (1990) Field measurements of filtration and respiration rates in Mytilus edulis L. An assessment of methods. Sarsia 75:213-216

Ward JE, Beninger PG, MacDonald BA, Thompson RJ (1991) Direct observations of feeding structures and mechanisms in bivalve molluscs using endoscopic examination and video image analysis. Mar Biol 111:287-291

Ward JE, MacDonald BA, Thompson RJ, Beninger PG (1993) Mechanisms of suspension feeding in bivalves: resolution of current controversies by means of endoscopy. Limnol Oceanogr 38:265-272

Ward JE, Newell RIE, Thompson RJ, MacDonald BA (1994) In vivo studies of suspension-feeding processes in the eastern oyster, Crassostrea virginica (Gmelin). Biol Bull 186 $221-240$

Ward JE, Targett NM (1989) Influence of marine microalgal metabolites on the feeding behaviour of the blue mussel Mytilus edulis. Mar Biol 101:313-321

Widdows J (1978) Physiological indices of stress in Mytilus edulis. J Mar Biol Ass UK 58:125-142

Widdows J (1985a) Physiological measurements. In: Bayne BL et al. (eds) The effects of stress and pollution on marine animals. Praeger Scientific, New York, p 3-45

Widdows J (1985b) Physiological procedures. In: Bayne BL et al. (eds) The effects of stress and pollution on marine animals. Praeger Scientific, New York, p 161-178

Widdows J (1.993) Marine and estuarine invertebrate toxicity tests. In: Calow P (ed) Handbook of ecotoxicology. Blackwell, London, p 145-164

Widdows J, Donkin P, Brinsley MD, Evans SV, Salkeld PN Franklin A, Law RJ. Waldock MJ (1995) Scope for growth and contaminant levels in North Sea mussels Mytilus edulis. Mar Ecol Prog Ser 127:131-148

Widdows J, Donkin P. Salkeld PN, Cleary JJ, Lowe DM Evans SV, Thompson PE (1984) Relative importance of environmental factors in determining physiological differences between two populations of mussels (Mytilus edulis). Mar Ecol Prog Ser 17:33-47

Widdows J, Johnson D (1988) Physiological energetics of Mytilus edulis: scope for growth. Mar Ecol Prog Ser 46:13-121

Wildish DJ, Kristmanson DD, Saulnier AM (1992) Interactive effect of velocity and seston concentration on giant scallop feeding inhibition. J Exp Mar B1ol Ecol 155:161-168

Wildish DJ, Miyares MP (1990) Filtration rate of blue mussels 
as a function of flow velocity: preliminary experiments J Exp Mar Biol Ecol 142:213-219

Wildish DJ, Saulnier AM (1992) The effect of velocity and flow direction on growth of juvenile and adult giant scallops. J Exp Mar Biol Ecol 155:133-143

Wildish DJ, Saulnier AM (1993) Hydrodynamic control of filtration in Placopecten magellanicus. J Exp Mar Biol Ecol 174:65-82

Willows RI (1992) Optimal digestive investment: a model for filter feeders experiencing variable diets. Limnol Oceanogr 37:829-847

Winter JE (1974) Growth in Mytilus edulis using different types of food. Ber Dt Wiss Kommn Meeresforsch 23 $360-375$

This review was submitted to the editor
Winter JE (1976) Feeding experiments with Mytilus edulis L II. The influence of suspended silt in addition to algal suspensions on growth. 10th European Symposium on Marine Biology, Vol 1. Inst Mar Sci Res, Bredene. Universa Press, Wetteren, p 583-600

Winter JE, Langton RW (1976) Feeding experiments with Mytilus edulis L at small laboratory scale. I. The influence of the total amount of food ingested and food on growth 10th European Symposium on Marine Biology, Vol 1. Inst Mar Sci Res, Bredene. Universa Press, Wetteren, p $565-581$

Zurburg W, Smaal A, Héral M, Dankers N (1994) Seston dynamics and bivalve feeding in the Bay of MarennesOléron (France). Neth J Aquat Ecol 28:459-466

Manuscript first received: February 29, 1996 Revised version accepted: July 24, 1996 